\title{
Методы усиления фототока ближнего инфракрасного диапазона в гетероструктурах Ge/Si с квантовыми точками Ge
}

\author{
А.А. Блошкин ${ }^{1,2}$, А.И. Якимов ${ }^{1}$, В.В. Кириенко ${ }^{1}$, А.В. Двуреченский ${ }^{1,2}$, Д. Е. Уткин ${ }^{1,2}$ \\ ${ }^{1}$ Институт физики полупроводников им. А.В. Ржанова, Новосибирск, 630090, пр. Академика \\ Лаврентьева 13. \\ ${ }^{2}$ Новосибирский государственный университет, Новосибирск, 630090, ул. Пирогова 2 \\ тел:+7 (383) 333-28-32, факс:+7 (383) 333-28-32, эл. почта: bloshkin@isp.nsc.ru
}

DOI 10.34077/RCSP2021-27

Исследованы различные методы усиления фотоотклика в ближем инфракрасном диапазоне гетросструктур $\mathrm{Ge} / \mathrm{Si}$ с квантовыми точками $\mathrm{Ge}$, сопряженных с различными поверхностными наноструктарами. С помощью математического моделирования установлены пространственные конфигурации электромагнитных полей, в таких гетероструктрах, а так же спектральная зависимость фактора усиления интенсивности электрического поля.

Рассматривались три основных типа структур. Первый тип гетероструктур представлял собой слои квантовых точек Ge выращенных на подложке $\mathrm{Si}$ и сопряженных с двумерными квадратными решетками круглых отверстий различного диаметра в золотой пленке, выступающими в качестве метаповерхностей, позволяющих преобразовать внешнее электромагнитное излучение в поверхностные плазмонные моды на границе Au-Si. Для такого типа фотопроводящих структур обнаружено, что величина плазмонного усиления поля, как функция диаметра отверстий демонстрирует максимум, при котором происходит смена блоховских плазмон-поляритонных мод, распространяющихся вдоль границы раздела $\mathrm{Au}-\mathrm{Si}$ на локализованные плазмонные моды [1].

Второй тип гетероструктур выращивался на подложках кремний-на изоляторе и в качетсве поверхностной наноструктуры имел массив металлических дисков, выполненных из различных металлов, таких как алюминий или золото, с адгезионным слоем титана. Показано, что таких гетероструктурах возникают локализованные плазмонные моды на гетерогранице металл-кремний и моды планарного волновода, формирующегося из-за разницы показателей преломления кремния и захороненного слоя $\mathrm{SiO}_{2}$. Обнаружено, что введение адгезионных слоев, необходимых для формирования стабильных наноструктур из благородных металлов, ведет к подавлению поверхностного плазмонного резонанса. Выбор алюминиевых нанодисков, не требующих адгезионных слоев, позволяет повысить эффективность фотоприемников в 40 раз на длине волны 1.2 мкм и в 15 раз при длине волны 1.65 мкм. [2]

Гетероструктры третьего типа представляли собой слои квантовых точек Ge выращенных на подложке кремний-на-изоляторе и сопряженные с фотонным кристаллом в виде переодической решетки отверстий в слое кремния с гексагональной и квадратной симметрией. Обнаружено, что встраивание слоев квантовых точек $\mathrm{Ge} / \mathrm{Si}$ в двумерный фотонный кристалл (ФК) приводит к многократному (до 5 раз) усилению фототока в ближнем инфракрасном диапазоне. [3]

Работа профинансирована Российским научным фондом (проект 19-12-00070).

\section{Лuтература}

[1] А. И. Якимов, А.А. Блошкин, А.В. Двуреченский//Письма в ЖЭТФ, 2019, т.110, вып.6, с. 393-399.

[2] А. И. Якимов и др. // ФТП, 2021, т. 55, вып. 7, с. 596-601.

[3] А.И. Якимов и др.// Письма в ЖЭТФ, 2021, т. 113, вып. 8, с. 501-506. 